\title{
Phase Transformation Behavior and Shape Memory Characteristics of Ti-Ni-Cu-Mo Alloys
}

\author{
Tae-Hyun Nam ${ }^{1}$, Jung-Phil Noh ${ }^{1}$, Shin-Goo Hur ${ }^{2}$, Ji-Soon Kim ${ }^{3}$ and Seung-Baik Kang ${ }^{4}$ \\ ${ }^{1}$ Division of Materials Engineering, Gyeongsang National University \& ERI, Gyeongnam 660-701, Korea \\ ${ }^{2}$ Biosmart Ltd, Ulsan 689-890, Korea \\ ${ }^{3}$ Department of Materials Science and Engineering, Ulsan University, Ulsan 680-749, Korea \\ ${ }^{4}$ Seoul Municipal Boramae Hospital, Seoul 156-102, Korea
}

Phase transformation behavior, the shape memory characteristics and the superelasticity of Ti-Ni-Cu-Mo alloys have been investigated by means of electrical resistivity measurements, $\mathrm{X}$-ray diffraction, thermal cycling tests under constant load and tensile tests. A fully annealed $\mathrm{Ti}-44.7 \mathrm{Ni}-5 \mathrm{Cu}-0.3 \mathrm{Mo}$ alloy transformed in two-stage, i.e., the B2-B19-B19' on cooling and the B19'-B19-B2 on heating. Fully annealed Ti$39.7 \mathrm{Ni}-10 \mathrm{Cu}-0.3 \mathrm{Mo}, \mathrm{Ti}-34.7 \mathrm{Ni}-15 \mathrm{Cu}-0.3 \mathrm{Mo}$ and $\mathrm{Ti}-29.7 \mathrm{Ni}-20 \mathrm{Cu}-0.3 \mathrm{Mo}$ alloys transformed in one-stage on, i.e., from the $\mathrm{B} 2$ to the $\mathrm{B} 19$ on cooling and from the B19 to B2 on heating. The maximum recoverable elongation deceased from 6.0 to $2.4 \%$ with increasing $\mathrm{Cu}$-content from 5 to 20 at\%. Transformation hysteresis associated with the B2-B19 transformation decreased from 11 to $5 \mathrm{~K}$ with increasing Cu-content from 5 to 20 at\%. Substitution of $\mathrm{Mo}$ for $\mathrm{Ni}$ in $\mathrm{Ti}-\mathrm{Ni}-\mathrm{Cu}$ alloys improved the superelasticity.

(Received November 19, 2001; Accepted April 15, 2002)

Keywords: titanium-nickel-copper-molybdenum alloys, transformation behavior, shape memory characteristics, superelasticity

\section{Introduction}

The B2-B19 transformation in the Ti-Ni-Cu alloys has been known to be very attractive in applications for an actuator, since it showed relatively large transformation elongation $(2.5-3.2 \%)$ and small hysteresis $(4-12 \mathrm{~K}) .{ }^{1)}$ The B2$\mathrm{B} 19$ transformation was observed in $\mathrm{Ti}-\mathrm{Ni}-\mathrm{Cu}$ alloys whose $\mathrm{Cu}$-content is more than 7.5 at\%., ${ }^{2,3)}$ In a practical point of view, however, the B2-B19 transformation in $\mathrm{Ti}-\mathrm{Ni}-\mathrm{Cu}$ alloys whose $\mathrm{Cu}$-content is lower than 10 at\% seems to be not available for applications, because the B19 and the B19' martensites coexist at any temperatures in the alloys. ${ }^{1,3)}$ In order to apply shape memory alloys to an actuator, they should be deformed to wire form. On the other hand, $\mathrm{Ti}-\mathrm{Ni}-\mathrm{Cu}$ alloys whose $\mathrm{Cu}$-content is more than 12.5 at\% are so brittle that a plastic deformation is almost impossible. ${ }^{1)}$ Therefore, it is desirable to induce only the B2-B19 transformation in $\mathrm{Ti}-\mathrm{Ni}-\mathrm{Cu}$ alloys with low $\mathrm{Cu}$ content which show good plastic deformability.

Substitution of Mo for $\mathrm{Ni}$ in a Ti-Ni binary alloy was known to decrease the B2-B19' transformation start temperature largely and induce the $\mathrm{R}$ phase transformation. ${ }^{4,5)}$ Therefore, it was expected that substitution of Mo for $\mathrm{Ni}$ in $\mathrm{Ti}-$ $\mathrm{Ni}-\mathrm{Cu}$ alloys suppressed the B2-B19' transformation also and that induced the B2-B 19 transformation. Recently, the present authors found that substitution of Mo for $\mathrm{Ni}$ in a $\mathrm{Ti}-$ $45 \mathrm{Ni}-5 \mathrm{Cu}$ alloy induced the B19 martensite. ${ }^{6)}$ In addition, they found also that shape memory characteristics and superelasticity of a $\mathrm{Ti}-45 \mathrm{Ni}-5 \mathrm{Cu}$ alloy were improved largely by substitution of Mo. ${ }^{7)}$ However, details of phase transformation behavior, the shape memory characteristics and the superplasticity of $\mathrm{Ti}-\mathrm{Ni}-\mathrm{Cu}-\mathrm{Mo}$ alloys are not known well. The purpose of the present study is to investigate phase transformation behavior, the shape memory characteristics and the superelasticity of $\mathrm{Ti}-\mathrm{Ni}-\mathrm{Cu}-\mathrm{Mo}$ alloys.

\section{Experimental Procedure}

50Ti-(49.7- $X) \mathrm{Ni}-\mathrm{XCu}-0.3 \mathrm{Mo}(\mathrm{at} \%)(X=5,10,15,20)$ alloy ingots were prepared by vacuum induction melting in a graphite crucible. After hot rolled into $\Phi 3 \mathrm{~mm}$ rods at $1123 \mathrm{~K}$, they were deformed to $\Phi 1.5 \mathrm{~mm}$ wires or $1.2 \mathrm{~mm}$ sheets by cold working. Specimens for electrical resistivity measurements, thermal cycling tests under constant load and tensile tests were prepared from the wires. Specimens for X-ray diffraction were prepared from the sheets. Since a Ti-29.7Ni-20Cu-0.3Mo alloy was unable to be hot rolled, specimens were cut from the ingot directly. All specimens were fully annealed at $1123 \mathrm{~K}$ for $3.6 \mathrm{ks}$ in vacuum, and then electropolished with an electrolyte which consists of $95 \% \mathrm{CH}_{3} \mathrm{COOH}$ and $5 \% \mathrm{HClO}_{4}$ in volume.

In order to investigate the transformation behavior, electrical resistivity measurements, X-ray diffraction were carried out. Electrical resistivity measurements were made by means of typical four terminal technique at the cooling/heating rate of $0.017 \mathrm{~K} / \mathrm{s}$. X-ray diffractions were made in a temperature range between 383 and $83 \mathrm{~K}$ using $\mathrm{CuK} \alpha$. Thermal cycling tests under constant $\operatorname{load}^{8)}$ were made to investigate the shape memory characteristics. Tensile tests were carried out to investigate the superelasticity with a strain rate of $6.6 \times 10^{-5} \mathrm{~s}^{-1}$.

\section{Results and Discussion}

\subsection{Phase transformation behavior of $\mathrm{Ti}-\mathrm{Ni}-\mathrm{Cu}-\mathrm{Mo}$ al- loys}

Figures 1(a)-(d) show electrical resistivity vs. temperature curves of Ti-44.7Ni-5Cu-0.3Mo, Ti-39.7Ni-10Cu-0.3Mo, $\mathrm{Ti}-34.7 \mathrm{Ni}-15 \mathrm{Cu}-0.3 \mathrm{Mo}$ and $\mathrm{Ti}-29.7 \mathrm{Ni}-20 \mathrm{Cu}-0.3 \mathrm{Mo}$ alloys, respectively. In the curve of (a), on cooling the specimen from $380 \mathrm{~K}$, electrical resistivity starts to decrease abruptly at $277 \mathrm{~K}$. On further cooling the specimen, it starts to increase 

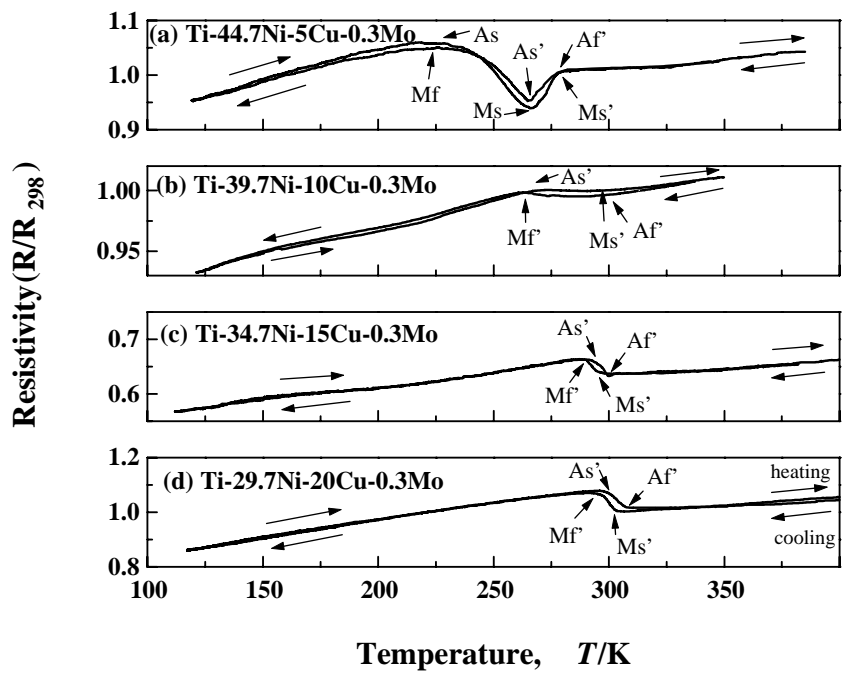

Fig. 1 Electrical resistivity vs. temperature curves of $\mathrm{Ti}-\mathrm{Ni}-\mathrm{Cu}-\mathrm{Mo}$ alloys.

at $265 \mathrm{~K}$ and then has the maximum at $225 \mathrm{~K}$. On heating the specimen, electrical resistivity increases up to $229 \mathrm{~K}$ and then decreases. On further heating, it starts to increase at $266 \mathrm{~K}$, and then its increasing rate decreases at $280 \mathrm{~K}$. From the previous study, ${ }^{6}$ the abrupt decrease in resistivity at $277 \mathrm{~K}$ on cooling was known to be due to the B2-B19 transformation and the increase in resistivity at $265 \mathrm{~K}$ on cooling was done to be due to the B19-B19' transformation. The decrease in resistivity at $229 \mathrm{~K}$ on heating was ascribed to the B19'-B19 transformation and the increase in resistivity at $266 \mathrm{~K}$ on heating was done to the B19-B2 transformation.

In the curve of (b), on cooling the specimen from $347 \mathrm{~K}$, electrical resisti vity decreases, and then starts to increase slightly at $285 \mathrm{~K}$. On further cooling, it starts to decrease at $268 \mathrm{~K}$. On heating the specimen, it increases up to $263 \mathrm{~K}$, and then it decreases. On further heating, it starts to increase at $300 \mathrm{~K}$. In the curve of (c), on cooling the specimen, electrical resistivity decreases gradually, and then starts to increase at $294 \mathrm{~K}$. On further cooling, it starts to decrease at $290 \mathrm{~K}$. On heating the specimen, it increases up to $295 \mathrm{~K}$, and then decreases. On further heating, it starts to increase at $299 \mathrm{~K}$. In the curve of (d), on cooling the specimen, electrical resistivity decreases gradually, and then starts to increase at $302 \mathrm{~K}$. On further cooling, it starts to decrease at $296 \mathrm{~K}$. On heating the specimen, it increases up to $300 \mathrm{~K}$, and then decreases. On further heating, it starts to increase at $306 \mathrm{~K}$.

In order to explain the electrical resistivity curves of Figs. 1(b)-(d), X-ray diffraction experiments were made with successively cooling and heating specimens. Figure 2 shows $\mathrm{X}$ ray diffraction patterns of a $\mathrm{Ti}-39.7 \mathrm{Ni}-10 \mathrm{Cu}-0.3 \mathrm{Mo}$ alloy. At $298 \mathrm{~K}$, a diffraction peak corresponding to the B2 parent phase appears. The diffraction peak designated by $\mathrm{Cu}$ is originated from the specimen holder. On cooling the specimen, intensity of the diffraction peak of the B2 phase decreases, while the diffraction peaks of the B19 martensite appear as seen in the diffraction pattern obtained at $253 \mathrm{~K}$. On further cooling, the diffraction peak of the B2 phase disappears, and only those of the B19 martensite are found as seen in the pattern obtained at $213 \mathrm{~K}$. Even cooling the specimen down to $83 \mathrm{~K}$, only diffraction peaks of the B19 martensite

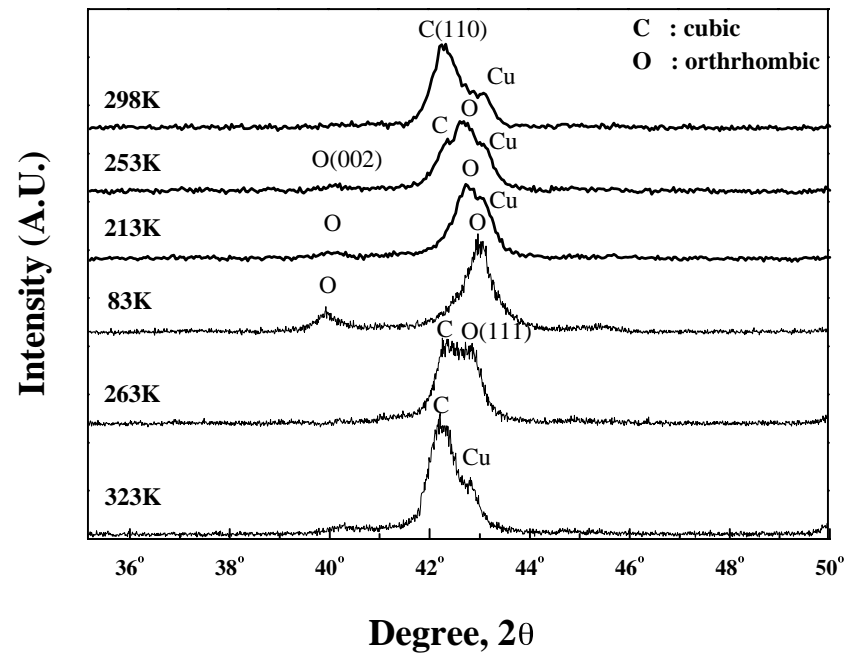

Fig. 2 X-ray diffraction patterns of a Ti-39.7Ni-10Cu-0.3Mo alloy.

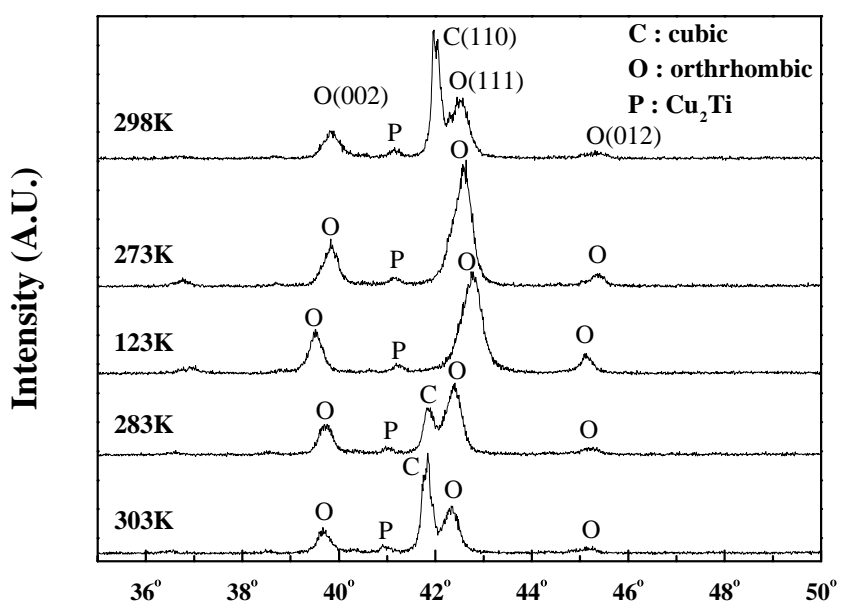

Degree, $2 \theta$

Fig. 3 X-ray diffraction patterns of a Ti-34.7Ni-15Cu-0.3Mo alloy.

are observed, and any diffraction peaks corresponding to the B19' martensite are not found. On heating the specimen, the diffraction peak of the B2 phase appears at $263 \mathrm{~K}$. On further heating, diffraction peaks of the B19 martensite disappear, and only that of the B2 phase is observed as shown in the pattern obtained at $323 \mathrm{~K}$. Peak shifts in X-ray diffraction patterns during heating and cooling are attributed to temperature dependence of lattice parameters. Therefore, in Fig. 1(b), the slight increase in resistivity at $281 \mathrm{~K}$ on cooling is attributed to the B2-B19 transformation and the decrease in resistivity at $263 \mathrm{~K}$ on heating is done to the B19-B2 transformation.

Figure 3 shows X-ray diffraction patterns of a $\mathrm{Ti}-34.7 \mathrm{Ni}-$ $15 \mathrm{Cu}-0.3 \mathrm{Mo}$ alloy. At $298 \mathrm{~K}$, diffraction peaks corresponding to the B2 parent phase and the B19 martensite appear. In addition, the diffraction peak corresponding to $\mathrm{Cu}_{2}$ Ti phase is found in the pattern. On cooling the specimen, the diffraction peak of the B2 phase disappears, while intensity of them of the B19 martensite increases as seen in the diffraction pattern obtained at $273 \mathrm{~K}$. Even cooling the specimen down to $123 \mathrm{~K}$, only diffraction peaks of the $\mathrm{B} 19$ martensite and $\mathrm{Cu}_{2} \mathrm{Ti}$ are observed. On heating the specimen, the diffraction peak of the B2 phase appears at $283 \mathrm{~K}$. On further heating, intensity of 
diffraction peaks of the B19 martensite decreases, while that of the B2 phase increases as seen in the pattern obtained at $303 \mathrm{~K}$. Therefore, the increase in resistivity at $294 \mathrm{~K}$ on cooling in Fig. 1(c) is attributed to the B2-B19 transformation and the decrease in resistivity at $295 \mathrm{~K}$ on heating in Fig. 1(c) is done to the B19-B2 transformation.

$\mathrm{X}$-ray diffraction patterns of a Ti-29.7Ni-20Cu-0.3Mo alloy are shown in Fig. 4. At $308 \mathrm{~K}$, diffraction peaks corresponding to the B2 parent phase, the B19 martensite appear and $\mathrm{Cu}_{2} \mathrm{Ti}$ appear. On cooling the specimen, the intensity of the diffraction peak of the $\mathrm{B} 2$ phase decreases, while those of the B19 martensite increase as can be seen in the pattern obtained at $298 \mathrm{~K}$. On further cooling, at $88 \mathrm{~K}$, the diffraction peak of the B2 phase disappears. On heating the specimen, at $313 \mathrm{~K}$, diffraction peak of the B2 phase appears. Therefore, the increase in resistivity at $302 \mathrm{~K}$ on cooling in Fig. 1(d) is attributed to the B2-B19 transformation and the decrease in resistivity at $300 \mathrm{~K}$ on heating in Fig. 1(d) is done to the B19-B2 transformation.

From Figs. 1-4, it is concluded that a Ti-44.7Ni$5 \mathrm{Cu}-0.3 \mathrm{Mo}$ alloy transforms in two-stages on cooling and heating, i.e., the $\mathrm{B} 2-\mathrm{B} 19-\mathrm{B} 19^{\prime}$ on cooling and the B19'B19-B2 on heating. In addition, it is concluded that Ti-39.7Ni-10Cu-0.3Mo, Ti-34.7Ni-15Cu-0.3Mo and Ti$29.7 \mathrm{Ni}-20 \mathrm{Cu}-0.3 \mathrm{Mo}$ alloys transform in one-stage on cooling and heating, i.e., from the $\mathrm{B} 2$ to the $\mathrm{B} 19$ on cooling and from the B19 to B2 on heating. The B2-B19 transformation start temperature $\left(M s^{\prime}\right)$, its finish temperature $\left(M f^{\prime}\right)$, the B19-B2 transformation start temperature $\left(A s^{\prime}\right)$ and its finish temperature $\left(A f^{\prime}\right)$ were measured from Fig. 1. In addition, the B19-B19' transformation start temperature $(M s)$, its finish temperature $(M f)$ and the B19'-B19 transformation start temperature $(A s)$ were determined from the curve of Fig. 1(a). Results obtained are shown in Table 1 . With increasing $\mathrm{Cu}-$ content, transformation temperatures associated with the B2B19 transformation are found to rise.

It was known that a $\mathrm{Ti}-45 \mathrm{Ni}-5 \mathrm{Cu}$ transformed in onestage, i.e., from the $\mathrm{B} 2$ to the $\mathrm{B} 19^{\prime}$ on cooling and from the $\mathrm{B} 19^{\prime}$ to the $\mathrm{B} 2$ on heating. ${ }^{1,2)}$ In addition, it was known that $\mathrm{Ti}-40 \mathrm{Ni}-10 \mathrm{Cu}$ and $\mathrm{Ti}-35 \mathrm{Ni}-15 \mathrm{Cu}$ alloys transformed in two-

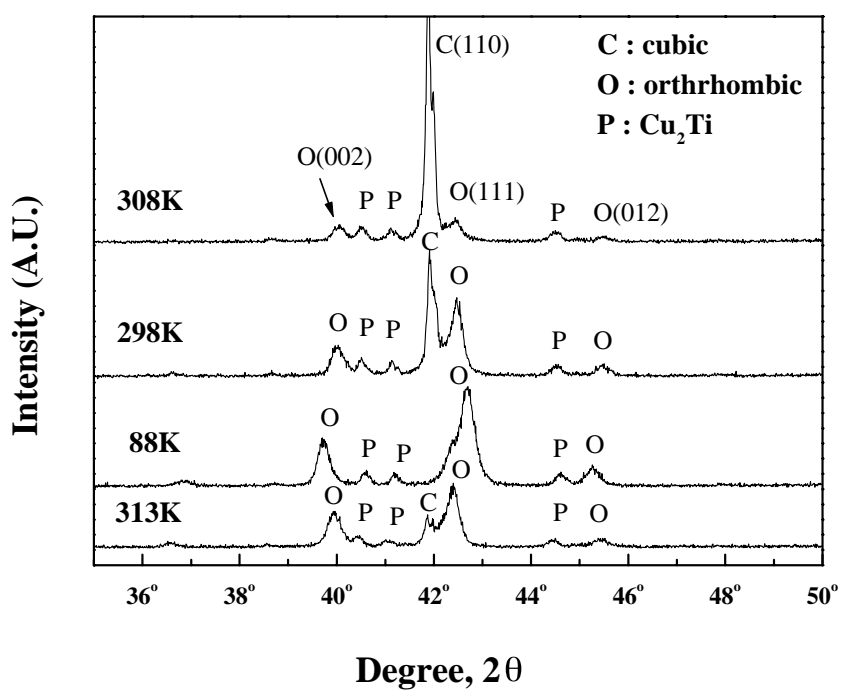

Fig. 4 X-ray diffraction patterns of a Ti-29.7Ni-20Cu-0.3Mo alloy. stages, i.e., the B2-B19-B19' on cooling and the B19'-B19-B2 on heating. ${ }^{1,2)}$ Comparing with Figs. 1-4, it is found that substitution of Mo for $\mathrm{Ni}$ in $\mathrm{Ti}-\mathrm{Ni}-\mathrm{Cu}$ alloys suppresses a formation of the B19' martensite and stabilizes the B19 martensite.

\subsection{Deformation behavior of $\mathrm{Ti}-\mathrm{Ni}-\mathrm{Cu}-\mathrm{Mo}$ alloys}

In order to investigate deformation behaviors of $\mathrm{Ti}-\mathrm{Ni}-\mathrm{Cu}-$ Mo alloys, tensile tests were made at $283 \mathrm{~K}$ where only the B2 parent phase exists in a $\mathrm{Ti}-44.7 \mathrm{Ni}-5 \mathrm{Cu}-0.3 \mathrm{Mo}$, the $\mathrm{B} 2$ and the $\mathrm{B} 19$ martensite coexist in a $\mathrm{Ti}-39.7 \mathrm{Ni}-10 \mathrm{Cu}-0.3 \mathrm{Mo}$ alloy and only the B19 martensite exists in a Ti-34.7Ni-15Cu0.3 Mo alloy. A Ti-29.7Ni-20Cu-0.3Mo alloy was so brittle that it was fractured prior to plastic deformation. Figures 5 (a)-(c) show stress-strain curves of Ti- $44.7 \mathrm{Ni}-5 \mathrm{Cu}-0.3 \mathrm{Mo}$, $\mathrm{Ti}-39.7 \mathrm{Ni}-10 \mathrm{Cu}-0.3 \mathrm{Mo}$ and $\mathrm{Ti}-34.7 \mathrm{Ni}-15 \mathrm{Cu}-0.3 \mathrm{Mo}$ alloys, respectively. Two plateaus are seen in the curve of (a). The plateau corresponding to about $50 \mathrm{MPa}$ is ascribed to the stress-induced B2-B19 transformation and that corresponding to $150 \mathrm{MPa}$ is done to the stress-induced B19-B19' transformation. Two plateaus are also found in the curve of (b). The plateau corresponding to $120 \mathrm{MPa}$ is as cribed to a rearrangement of the B19 martensite variants and that corresponding to about $250 \mathrm{MPa}$ is done to the stress induced B2-B19 transformation. One plateau is found in the curve of (c), which is ascribed to a rearrangement of the B19 martensite.

\subsection{Shape memory characteristics of $\mathrm{Ti}-\mathrm{Ni}-\mathrm{Cu}-\mathrm{Mo}$ al- loys}

Figure 6 shows elongation-temperature curves of a Ti$44.7 \mathrm{Ni}-5 \mathrm{Cu}-0.3 \mathrm{Mo}$ alloy. All the curves are characterized by two-stage elongation. Details of the curves will be ex-

Table 1 Transformation temperatures of $\mathrm{Ti}-\mathrm{Ni}-\mathrm{Cu}-\mathrm{Mo}$ alloys.

\begin{tabular}{ccccccccc}
\hline \multirow{2}{*}{ Cu-content } & \multicolumn{8}{c}{ Transformation temperatures (K) } \\
\cline { 2 - 8 } & $M s^{\prime}$ & $M f^{\prime}$ & $A s^{\prime}$ & $A f^{\prime}$ & $M s$ & $M f$ & $A s$ & $A f$ \\
\hline 5 & 277 & - & 266 & 280 & 265 & 225 & 229 & - \\
10 & 285 & 268 & 263 & 300 & & & & \\
15 & 294 & 290 & 295 & 299 & & & & \\
20 & 302 & 296 & 300 & 306 & & & & \\
\hline
\end{tabular}
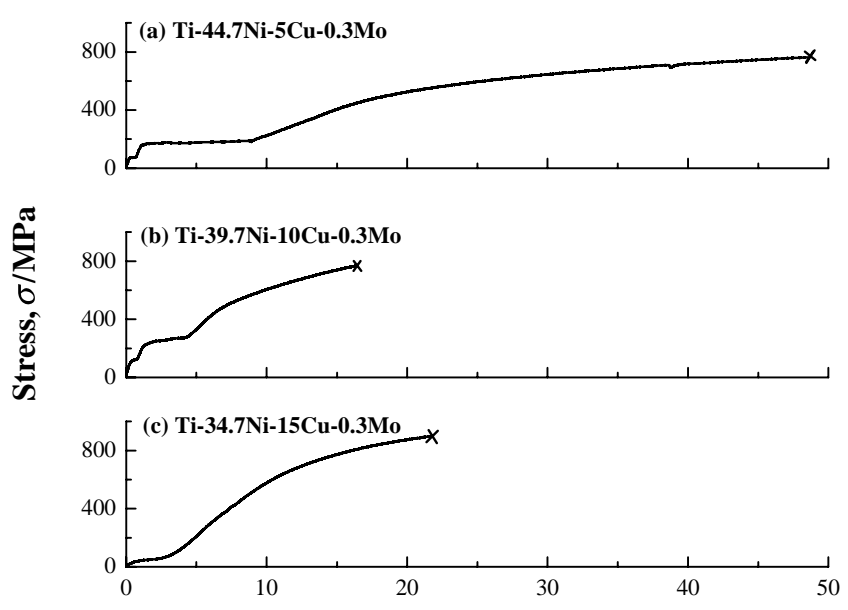

Strain, $\varepsilon(\%)$

Fig. 5 Stress-strain curves of Ti-Ni-Cu-Mo alloys deformed at $283 \mathrm{~K}$. 


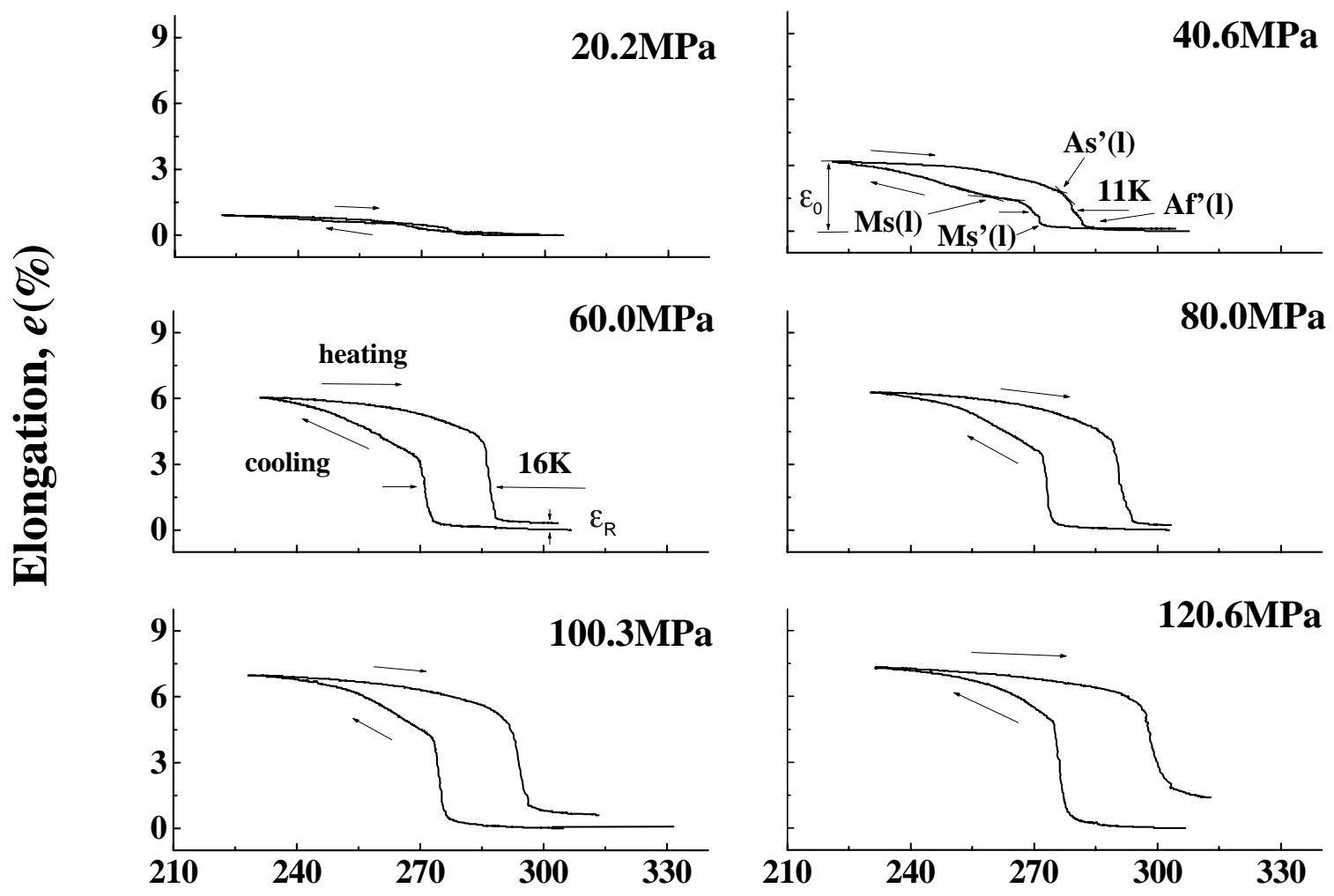

\section{Temperature, $T / K$}

Fig. 6 Elongation vs. temperature curves of a $\mathrm{Ti}-44.7 \mathrm{Ni}-5 \mathrm{Cu}-0.3 \mathrm{Mo}$ alloy.

plained referring to the curve obtained at $40.6 \mathrm{MPa}$. On cooling the specimen from $303 \mathrm{~K}$, the specimen starts to elongate suddenly at $273 \mathrm{~K}$. This abrupt elongation is attributed to the B2-B19 transformation, and therefore the temperature is defined as $M s^{\prime}(1)$. A tangential extrapolation method is used to determine the $M s^{\prime}(1)$, as indicated in the figure. On further cooling, a small elongation gradually continues, and then the rate of elongation starts to increase again at a temperature. This increase is due to the B19-B19' transformation, and therefore the temperature is defined as $M s(1)$. On further cooling, the elongation gradually increases, and then it is almost saturated. On heating, the elongation start to be recovered at a temperature of $A s(1)$. The recovery is attributed to the B19'-B19 transformation. On further heating, the elongation is recovered gradually, and then recovered abruptly at a temperature of $A s^{\prime}(\mathrm{l})$. This abrupt recovery is attributed to the B19-B2 transformation. Since the elongation at temperature below about $230 \mathrm{~K}$ is very small, the elongation between $M s^{\prime}(1)$ and $230 \mathrm{~K}$ is adopted as a transformation elongation $\left(\varepsilon_{0}\right)$ associated with the B2-B19-B19' transformation.

As seen in Fig. 6, the B2-B19 and the B19-B19' transformation are not well separated in curves obtained at the stress more than $60.0 \mathrm{MPa}$. This is attributed to the fact that the stress dependence of the transformation temperature of the B19-B19' transformation is larger than that of the B2-B19 transformation. ${ }^{8)}$ Very small residual elongation $\left(\varepsilon_{\mathrm{R}}\right)$ less than $0.3 \%$ is seen in the curve obtained at $80.6 \mathrm{MPa}$, and it becomes $0.6 \%$ at $100.3 \mathrm{MPa}$. In a $\mathrm{Ti}-45 \mathrm{Ni}-5 \mathrm{Cu}($ at $\%)$ alloy, it has been reported that a large $\varepsilon_{\mathrm{R}}$ more than $0.5 \%$ appeared at about $60 \mathrm{MPa}$ and that increased up to $1.1 \%$ with increasing the applied stress up to $99.0 \mathrm{MPa}$. $\varepsilon_{\mathrm{R}}$ is originated from plastic deformation. ${ }^{1)}$ Therefore, it is considered that substitution of Mo for $\mathrm{Ni}$ of a $\mathrm{Ti}-45 \mathrm{Ni}-5 \mathrm{Cu}($ at $\%)$ alloy increases the critical stress for slip deformation. The transformation hysteresis designated in the curves is found to be increase from 11 to $19 \mathrm{~K}$ with increasing applied stress from 40.6 to $100.3 \mathrm{MPa}$. The increase in hysteresis is ascribed to the facts that the B2$\mathrm{B} 19$ and B19-B19' transformation overlaps and $\varepsilon_{\mathrm{R}}$ increases with increasing applied stress.

Figures 7-9 show elongation-temperature curves of $\mathrm{Ti}-39.7 \mathrm{Ni}-10 \mathrm{Cu}-0.3 \mathrm{Mo}$, Ti-34.7Ni-15Cu-0.3Mo and $\mathrm{Ti}-$ $29.7 \mathrm{Ni}-20 \mathrm{Cu}-0.3 \mathrm{Mo}$ alloys. Irrespective of alloy compositions, all the curves are characterized by one-stage elongation due to the B2-B19 transformation. $\varepsilon_{0}$ associated with the B2-B19 transformation is defined as an elongation occurred between $M s^{\prime}(1)$ and $M f^{\prime}(1)$. It is to be noted here that $\varepsilon_{\mathrm{R}}$ of $\mathrm{Ti}-39.7 \mathrm{Ni}-10 \mathrm{Cu}-0.3 \mathrm{Mo}, \mathrm{Ti}-34.7 \mathrm{Ni}-15 \mathrm{Cu}-0.3 \mathrm{Mo}$ and $\mathrm{Ti}-29.7 \mathrm{Ni}-20 \mathrm{Cu}-0.3 \mathrm{Mo}$ alloys is less than $0.3 \%$ under the applied stress of about $120 \mathrm{MPa}$. In Ti-Ni-Cu alloys, $\varepsilon_{\mathrm{R}}$ was reported to be more than $0.5 \%$ under the similar stress level. ${ }^{1)}$ Transformation hysteresis associated with the B2-B19 transformation is found to decrease from 9 to $5 \mathrm{~K}$ with increasing $\mathrm{Cu}$-content from 10 to 20 at\%.

From Figs. 7-9, $M s^{\prime}(1)$ was measured, and then plotted against the applied stress in Fig. 10. As can be seen, $M s^{\prime}(1)$ increases linearly with increasing the applied stress. The temperature dependence of the stress required to induce the B2-B19 transformation in Ti-Ni-Cu-Mo alloys is al- 


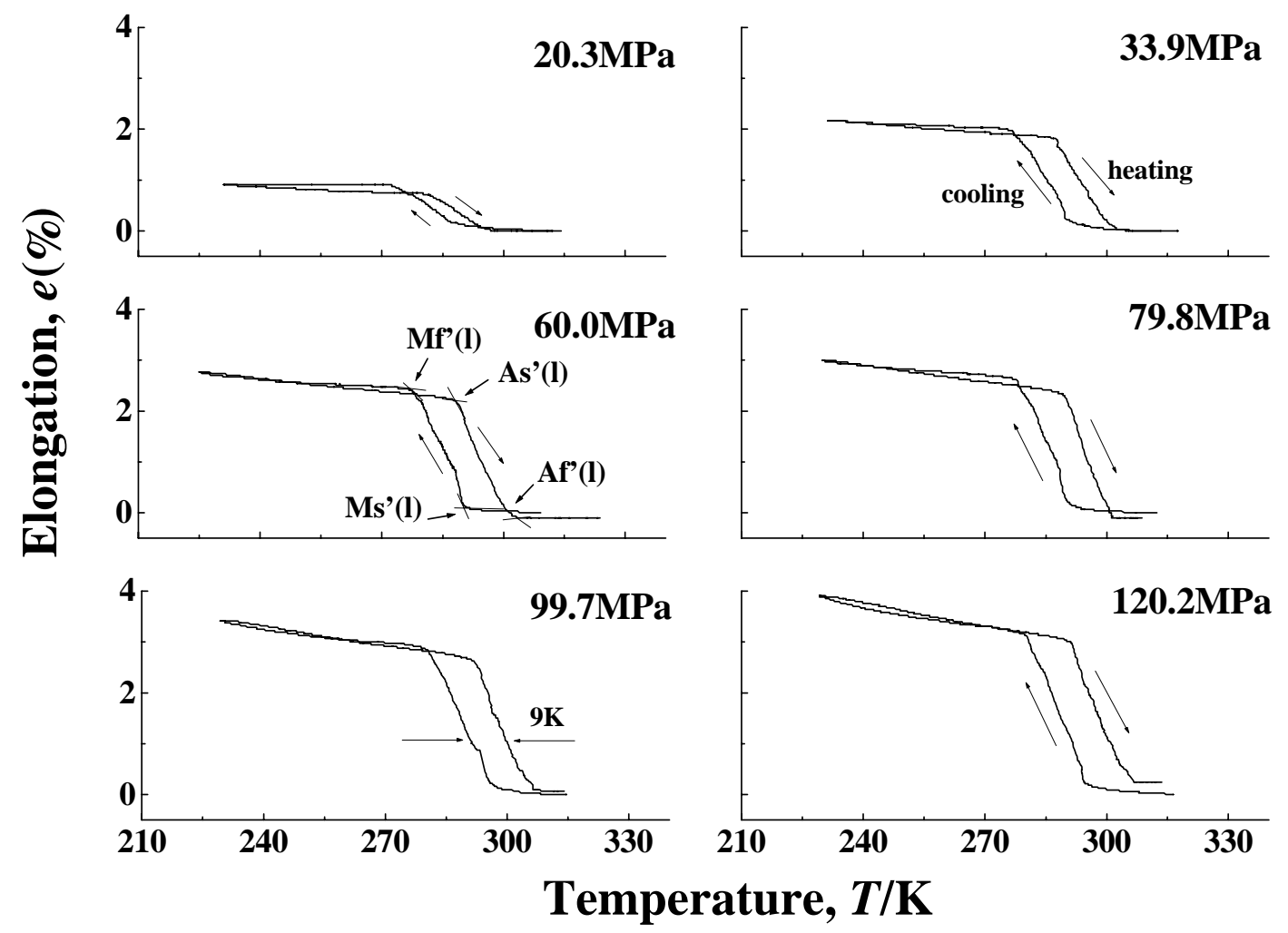

Fig. 7 Elongation vs. temperature curves of a Ti-39.7Ni-10Cu-0.3Mo alloy.

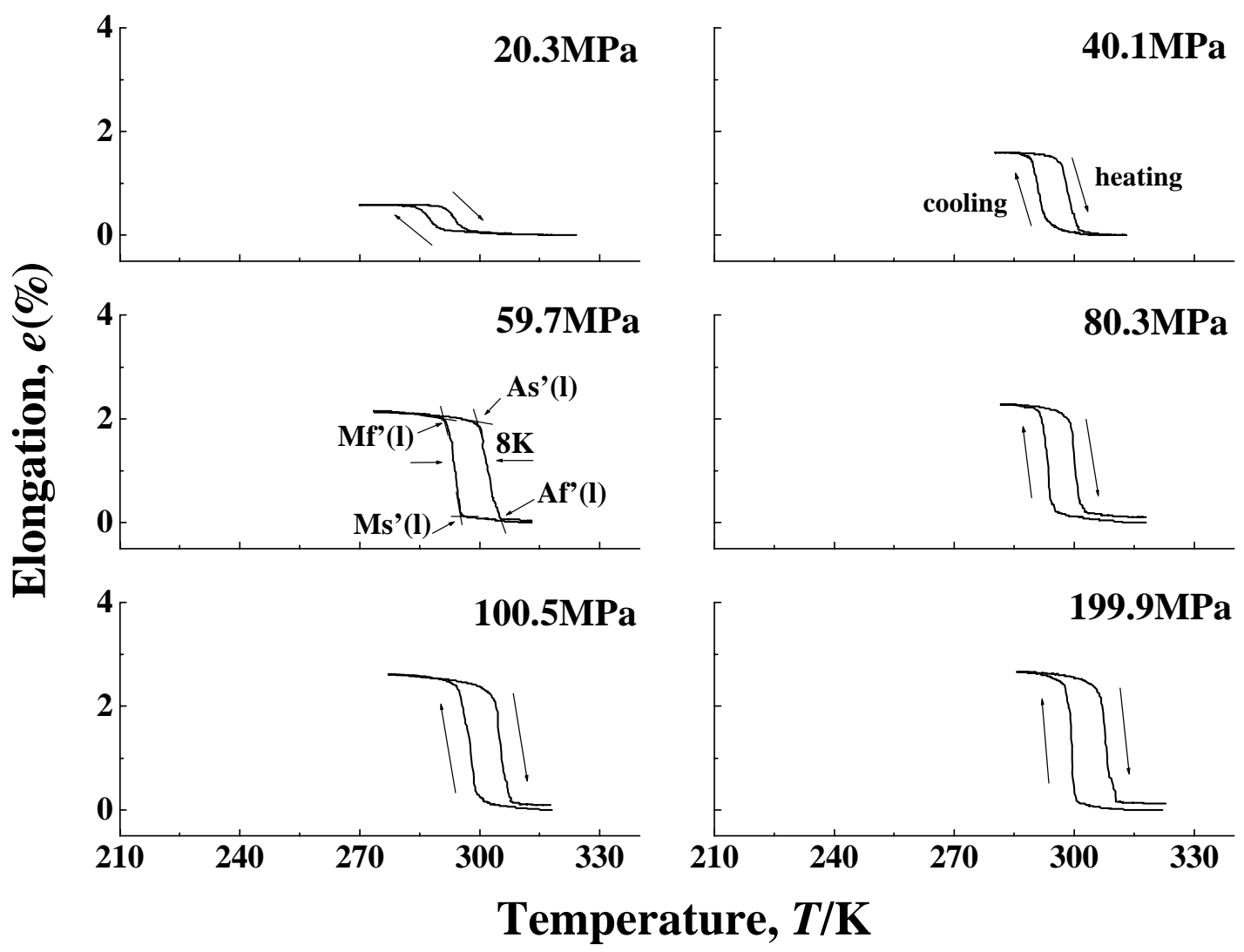

Fig. 8 Elongation vs. temperature curves of a Ti-34.7Ni-15Cu-0.3Mo alloy.

most constant without regard to the $\mathrm{Cu}$-content, i.e., about $8 \mathrm{MPa} / \mathrm{K}$, which is very similar to that of $\mathrm{Ti}-\mathrm{Ni}-\mathrm{Cu}$ alloys. ${ }^{1)} \varepsilon_{0}$ obtained from thermal cycling tests under various stresses is plotted against the applied stress, as shown in
Fig. 11. $\varepsilon_{0}$ plotted for a Ti-44.7Ni-5Cu-0.3Mo alloy is associated with the B2-B19-B19' transformation, while those for Ti-39.7Ni-10Cu-0.3Mo, Ti-34.7Ni-15Cu-0.3Mo and $\mathrm{Ti}-$ $29.7 \mathrm{Ni}-20 \mathrm{Cu}-0.3 \mathrm{Mo}$ alloys are associated with the B2-B19 


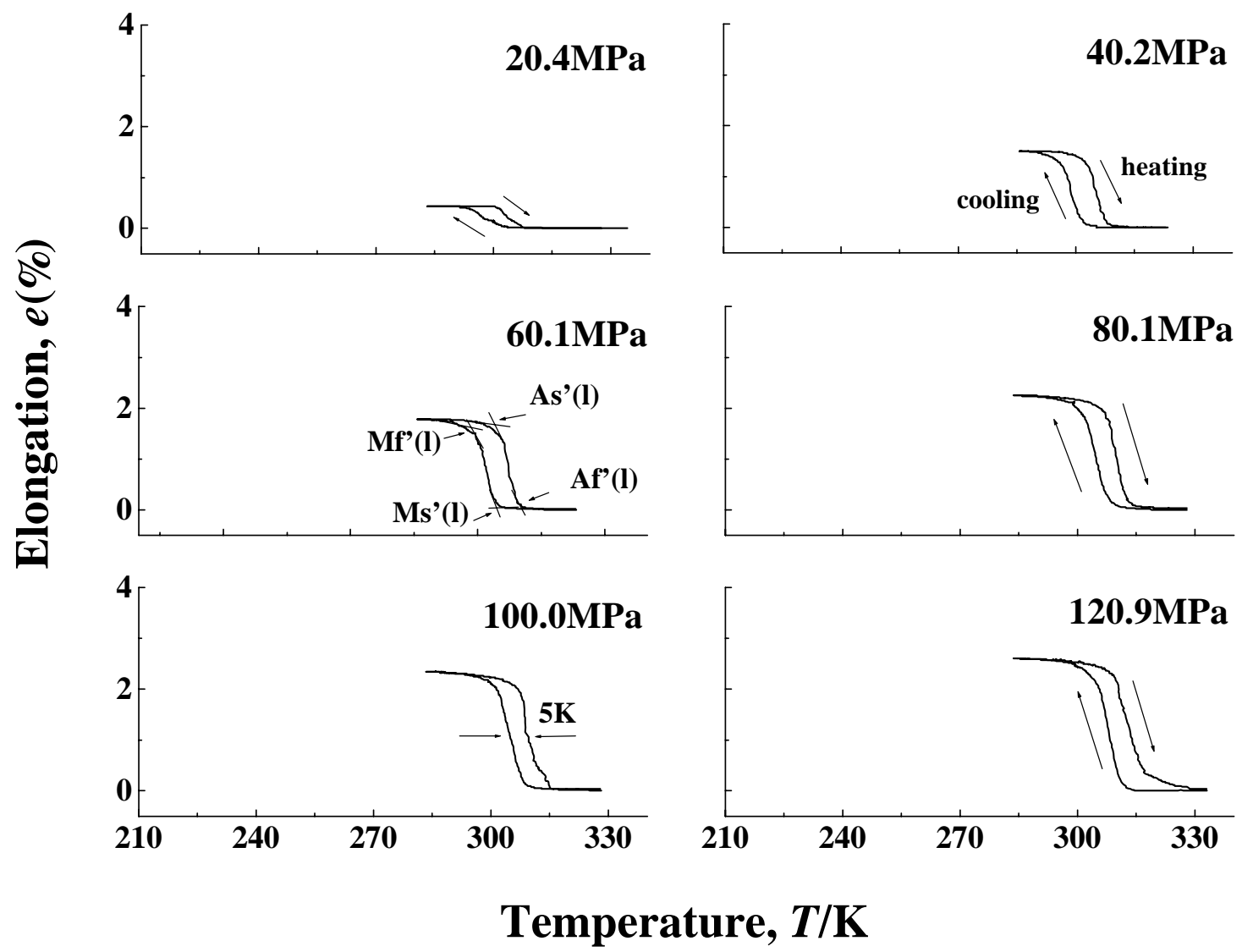

Fig. 9 Elongation vs. temperature curves of a Ti-29.7Ni-20Cu-0.3Mo alloy.

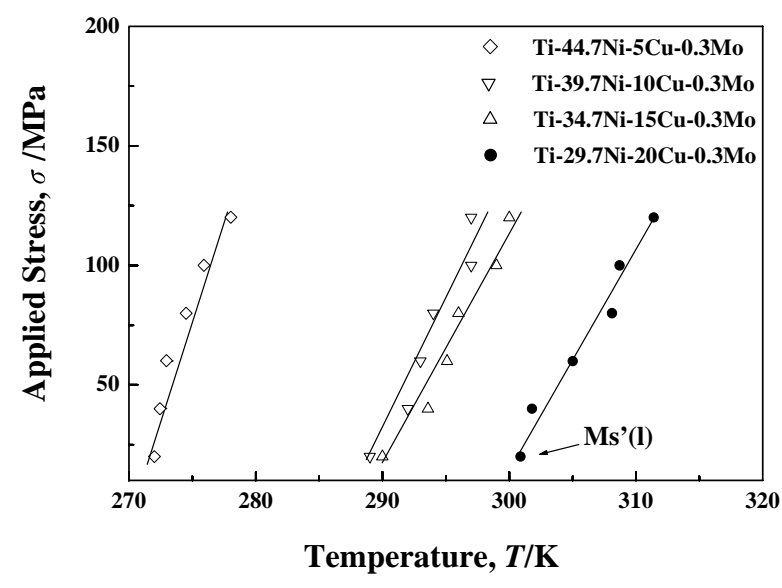

Fig. 10 Stress dependence of $M s^{\prime}(1)$ in Ti-Ni-Cu-Mo alloys.

transformation. Since residual elongation is nearly zero for stresses less than $60 \mathrm{MPa}$ in a $\mathrm{Ti}-44.7 \mathrm{Ni}-5 \mathrm{Cu}-0.3 \mathrm{Mo}$ alloy, the transformation elongation at $60 \mathrm{MPa}$ is the maximum recoverable one, $6.0 \%$. In a $\mathrm{Ti}-45 \mathrm{Ni}-5 \mathrm{Cu}$ alloy, the maximum recoverable elongation was known to be $3.3 \%$. ${ }^{1)}$ This is ascribed to the fact that the maximum recoverable elongation of a Ti-45Ni-5Cu alloy was associated with the B2-B19' transformation, while that of a $\mathrm{Ti}-44.7 \mathrm{Ni}-5 \mathrm{Cu}-0.3 \mathrm{Mo}$ alloy was done with the B2-B19-B19' transformation.

Since residual elongations are nearly zero for stresses less than $100 \mathrm{MPa}$ in $\mathrm{Ti}-39.7 \mathrm{Ni}-10 \mathrm{Cu}-0.3 \mathrm{Mo}$ and $\mathrm{Ti}-$ $34.7 \mathrm{Ni}-15 \mathrm{Cu}-0.3 \mathrm{Mo}$ alloys, the transformation elongations

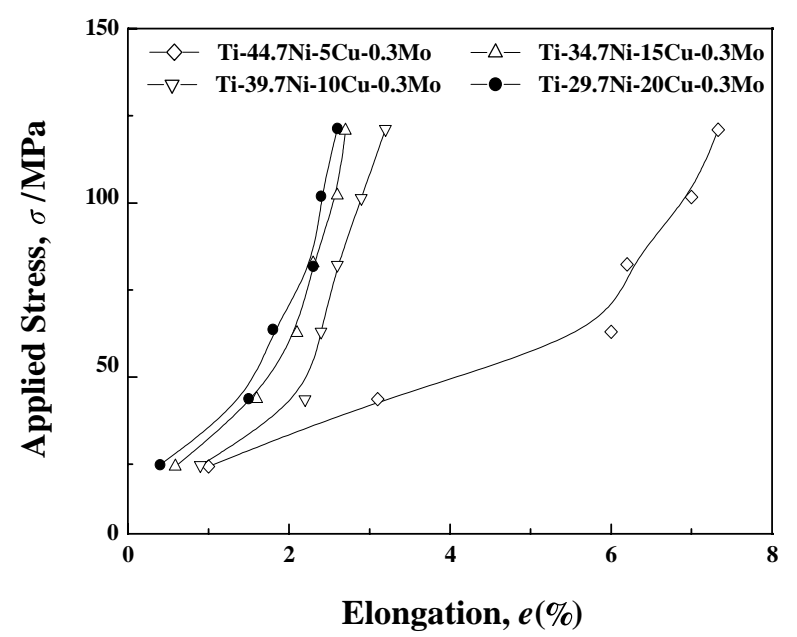

Fig. 11 Stress dependence of transformation elongations in $\mathrm{Ti}-\mathrm{Ni}-\mathrm{Cu}-\mathrm{Mo}$ alloys.

at $100 \mathrm{MPa}$ are the maximum recoverable ones which are $2.9 \%$ and $2.5 \%$, respectively. In the case of a $\mathrm{Ti}-29.7 \mathrm{Ni}-$ $20 \mathrm{Cu}-0.3 \mathrm{Mo}$ alloy, the residual elongation is not observed even at $120.4 \mathrm{MPa}$. Therefore, the transformation elongation at $120.4 \mathrm{MPa}$ is adopted as the maximum recoverable one, $2.4 \%$. The maximum recoverable elongations of $\mathrm{Ti}-39.7 \mathrm{Ni}-10 \mathrm{Cu}-0.3 \mathrm{Mo}, \mathrm{Ti}-34.7 \mathrm{Ni}-15 \mathrm{Cu}-0.3 \mathrm{Mo}$ and $\mathrm{Ti}-29.7 \mathrm{Ni}-20 \mathrm{Cu}-0.3 \mathrm{Mo}$ alloys associated with the $\mathrm{B} 2-$ B19 transformation are similar to those of $\mathrm{Ti}-40 \mathrm{Ni}-10 \mathrm{Cu}$, Ti-35Ni-15Cu and Ti-30Ni-20Cu alloys. ${ }^{1)}$ 


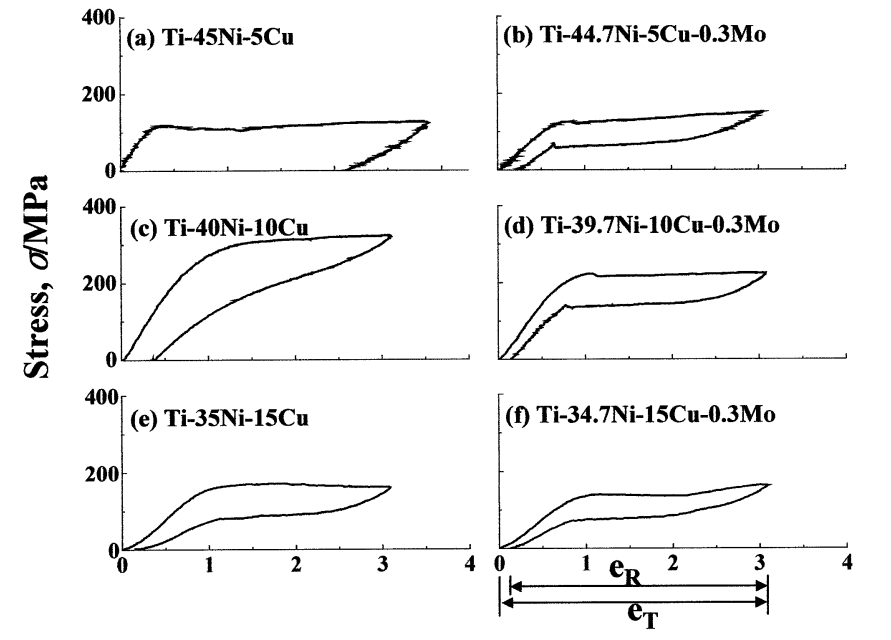

Strain, $\varepsilon(\%)$

Fig. 12 Stress-strain curves of $\mathrm{Ti}-\mathrm{Ni}-\mathrm{Cu}$ and $\mathrm{Ti}-\mathrm{Ni}-\mathrm{Cu}-\mathrm{Mo}$ alloys deformed at $A f^{\prime}$ of each alloy.

\subsection{Superelasticity of Ti-Ni-Cu-Mo alloys}

In order to investigate the superelasticity of $\mathrm{Ti}-\mathrm{Ni}-\mathrm{Cu}-\mathrm{Mo}$ alloys, tensile tests were made at $A f^{\prime}$ temperature, and the stress-strain curves obtained are shown in Fig. 12. For comparison, the stress-strain curves of $\mathrm{Ti}-\mathrm{Ni}-\mathrm{Cu}$ alloys fully annealed at $1123 \mathrm{~K}$ are also shown. All the alloys exhibit the superelasticity, except for a $\mathrm{Ti}-45 \mathrm{Ni}-5 \mathrm{Cu}$ alloy. The unrecovered strains after unloading were recovered completely in Ti$\mathrm{Ni}-\mathrm{Cu}-\mathrm{Mo}$ alloys on heating up to $373 \mathrm{~K}$, while those were not recovered completely in $\mathrm{Ti}-\mathrm{Ni}-\mathrm{Cu}$ alloys. The strain unrecovered after heating up to $373 \mathrm{~K}$ is due to plastic deformation. This suggests that substitution of Mo for Ni in Ti$\mathrm{Ni}-\mathrm{Cu}$ alloys increases the critical stress for slip deformation. The pseudoelastic recovery defined by $e_{\mathrm{R}} / e_{\mathrm{T}}$ in Ti-Ni-CuMo alloys is found to be $87 \%-94 \%$, while that in $\mathrm{Ti}-\mathrm{Ni}-\mathrm{Cu}$ alloys is found to be $33-90 \%$. This means that the superelasticity is improved by substitution of Mo for Ni in $\mathrm{Ti}-\mathrm{Ni}-$ $\mathrm{Cu}$ alloys. Complete superelasticity was observed in thermomechanically treated $\mathrm{Ti}-\mathrm{Ni}-\mathrm{Cu}$ alloys. ${ }^{9-11)}$

\section{Conclusions}

Phase transformation behavior, the shape memory characteristics and the superelasticity of $\mathrm{Ti}-\mathrm{Ni}-\mathrm{Cu}-\mathrm{Mo}$ alloys were investigated, and then the following conclusions were obtained.

(1) A Ti-44.7Ni-5Cu-0.3Mo alloy transformed in twostages on cooling and heating, i.e., the B2-B19-B19' on cooling and the B19'-B19-B2 on heating.

(2) $\mathrm{Ti}-39.7 \mathrm{Ni}-10 \mathrm{Cu}-0.3 \mathrm{Mo}, \quad \mathrm{Ti}-34.7 \mathrm{Ni}-15 \mathrm{Cu}-0.3 \mathrm{Mo}$ and $\mathrm{Ti}-29.7 \mathrm{Ni}-20 \mathrm{Cu}-0.3 \mathrm{Mo}$ alloys transformed in one-stage on cooling and heating, i.e., from the $\mathrm{B} 2$ to the $\mathrm{B} 19$ on cooling and from the B19 to B2 on heating.

(3) The maximum recoverable elongation deceased from 6.0 to $2.4 \%$ with increasing $\mathrm{Cu}$-content from 5 to 20 at\%.

(4) Transformation hysteresis associated with the B2B19 transformation decreased from 11 to $5 \mathrm{~K}$ with increasing $\mathrm{Cu}$-content from 5 to 20 at\% in constant loading test with no residual strain condition.

(5) Substitution of Mo for $\mathrm{Ni}$ in $\mathrm{Ti}-\mathrm{Ni}-\mathrm{Cu}$ alloys improved the superelasticity.

\section{Acknowledgements}

This work was supported by Korea Energy Management Corporation.

\section{REFERENCES}

1) T. H. Nam, T. Saburi and K. Shimizu: Mater. Trans., JIM 31 (1990) 959-967.

2) Y. Shugo, H. Hasegawa and T. Honma: Bull. Res. Inst. Mineral Dress. Metall., Tohoku Univ. 37 (1981) 79-86.

3) T. Fukuda, T. Chihara, Y. Tsuzuki and T. Saburi: Trans. Mat. Res. Soc. Jpn. 18B (1994) 1065-1068.

4) V. E. Gunter: Medical materials and implants with shape memory effect, (Tomck, 1998) pp. 180-182.

5) T. H. Nam, D. W. Jung, J. P. Noh and H. W. Lee: J. Mater. Sci. 36 (2001) 4181-4188.

6) T. H. Nam, J. P. Noh and D. W. Jung: J. Mater. Sci. Lett. 20 (2001) 713-715.

7) J. P. Noh, D. W. Jung, H. W. Lee and T. H. Nam: Mater. Sci. and Technol. 17 (2001) 1544-1550.

8) T. H. Nam, T. Saburi, Y. Kawamura and K. Shimizu: Mater. Trans., JIM 31 (1990) 262-269.

9) S. Miyazaki, I. Shiota, K. Otsuka and H. Tamura: MRS Int'l. Mtg. on Adv. Mats. 9 (1989) 153-158.

10) S. M. Tan and S. Miyazaki: Mater. Sci. Eng. A237 (1997) 79-86.

11) T. Ranucci, S. Besseghini and G. Airoldi: Mater. Sci. Forum 327-328 (2000) 143-146. 